Pobrane z czasopisma Annales H - Oeconomia http://oeconomia.annales.umcs.pl Data: 26/04/2023 01:33:46

DOI:10.17951/h.2017.51.3.71

\begin{tabular}{lcc}
\hline \multicolumn{2}{c}{ A N N A L E S } \\
UNIVERSITATIS MARIAE CURIE-SKŁODOWSKA \\
LUBLIN - POLONIA \\
VOL. LI, 3 & SECTIOH H \\
\hline
\end{tabular}

AGH University of Science and Technology

DAGMARA LEWICKA, PAULINA KARP-ZAWLIK, MONIKA PEC

dagal@poczta.fm, p.karpzawlik@poczta.fm, mpelczar@interia.pl

\title{
Organizational Trust and Normative Commitment
}

Zaufanie organizacyjne a przywiązanie normatywne

Keywords: organisational trust; horizontal trust; normative commitment; normative team commitment; Poland

Słowa kluczowe: zaufanie organizacyjne; zaufanie horyzontalne; przywiązanie normatywne; przywiązanie normatywne zespołowe; Polska

JEL code: M14; M12

\section{Introduction}

In the situation of almost unlimited possibilities of changing job, organizations are increasingly focused on retaining employees with core competencies and those offering added value to the enterprise.

The researchers' and practitioners' attention is focused on affective commitment as the one generating significant benefits to the organization, whereas the importance of normative commitment seems to be underestimated. It is often indicated in the literature sources that the normative commitment creates added value for the organization. The employees exhibiting a high level of normative commitment typically avail their energy and skills to the organization due to the fact that they feel a deep sense of such behavior [Valaei and Rezaei 2016, pp. 1663-1694]. The research also shows that this form of demeanor buoys up their affective commitment [Meyer et al. 2002, pp. 20-52]. 
The assumption about the impact of trust on the normative commitment is associated with two premises:

- Both phenomena are based on internalized values. In the case of trust, it seems that it is of great significance to share group common values and standards, the so-called trust based on group identification leading to sacrificing or deferring their sake for the particulars, relationships or group benefits [Fukuyama 1997]. By contrast, the normative commitment is associated with a sense of moral obligation and duty, which can also result in deferring particular interests of the individual.

- The second premise is based on the exchange theory, according to which, the value for the employee is constituted by the organization, supervisors or co-produced reciprocity in the form of positive behavior and attitudes e.g. sense of loyalty and duty [Turner 2004].

The few studies on the relationship between trust and organizational attachment point to the positive impact of trust on the organizational commitment [Brockner et al. 1997, pp. 558-583; Cascio 1993, pp. 95-104; Dirks and Ferrin 2002, pp. 450-467; Vanhala et al. 2016, pp. 46-61]. So far, however, little attention has been given to the impact of organizational trust on the normative commitment. The authors [Meyer and Allen 1991, pp. 61-89] indicate, however, that the normative commitment eventuates from both the family and workplace socialization processes, especially when values of loyalty and duty were accentuated. It is, therefore, justified to study the impact of organizational factors on this form of commitment.

Hence, the aim of this study is to identify the impact of organizational trust on the normative commitment in three dimensions (institutional, vertical and horizontal). To that end, multiple regression was used in order to do the research, both on literature and empirical methods. In this study, a hypothesis on the impact of institutional, vertical and horizontal trust on normative and team normative attachment was formulated.

\section{Literature review}

\subsection{Organisational trust}

To trust means to believe and expect that a partner of a relation will act in support of common interest [Gilson 2003, pp. 1453-1468], which will assure cooperation despite any risks [Blomqvist 2002 ]. Mutual trust assumes that neither party will contribute to the harm of the partner, taking advantage of partner's weaknesses [Morgan et al. 1994, pp. 20-38]. According to Koźmiński, trust is the basic condition of competitive advantage, reducing the costs of control and entailing tolerance, which is necessary for innovation and independent actions [Koźmiński 2004].

Organisational trust is defined as perceived credibility of organisation estimated through transparency, integrity, competence, kindness, and reliability, as well as based 
on personal experience and identification [Pirson and Malhotra 2008]. Many authors indicate that positive effect of strong organisational trust is the ability to keep the best employees in the organisation, their strong motivation, and willingness to invest effort in their work [Glińska-Neweś 2013, pp. 125-154]. Additionally, trust-based relations make the employees offer more valuable resources to the organisation, work better, and be more motivated to act innovatively [Vidotto et al. 2008, pp. 563-575]. The other authors [Reina and Reina 2006] state that mutuality is the base of organisational effectiveness. They indicate that a high level of trust positively affects organisations, allowing, among others, introducing organisational changes. Moreover, it is emphasised that trust supports establishing satisfactory business relations, which allows inter- and intra-organisational cooperation.

Studies on organisational trust focus mostly on interpersonal trust: among employees, called horizontal trust, between employees and their direct superior, i.e. vertical trust [Dirks and Ferrin 2002], and institutional trust (impersonal trust) towards an organisational entity [Cho and Park 2011, pp. 551-573].

Institutional trust concerns general organisation and company's management. It includes factors such as technologies, procedures, systems, resolutions, key goals and vision, competences, policy and justice [Ellonen et al. 2008, pp. 160-181]. It is shaped based on the efficiency of operations and the fairness of rules of functioning of particular structure levels and of the whole company.

Vertical trust refers to relation between the superior and the subordinate, characterised by asymmetry and dependence in terms of promotion, increase of salary, or work safety [Sitkin and Roth 1993, pp. 367-392]. It makes trust crucial for vertical relations. The subordinate decides whether he/she will trust the superior. Trust is a factor that is necessary for satisfaction in relations with the superior [Conger et al. 2000, pp. 747-767], and it is worth mentioning that the feeling of being trusted by the superior also contributes to this satisfaction. As a result of positive relations with the superior, employees engage in their work more [Zhang et al. 2008, pp. 111-132].

Horizontal trust is the belief that employee's actions can be relied on [Loon Hoe 2007, pp. 12-13]. It contributes to relation enrichment, develops cooperation and involvement, and facilitates information flow and knowledge creation [Connell et al. 2003, pp. 569-587]. Researchers who study this problem emphasise that trust is a condition of voluntary cooperation, an essential element of relation creation [Morgan and Hunt 1994, pp. 20-38], the base of open communication and dialogue, and promotes cooperative behaviour [Svensson 2006, pp. 132-152], which results in realisation of common goals [Gaur et al. 2011, pp. 1752-1781]. Expecting that a trusted person will not harm the trusting one increases the inclination to take risks and the belief that the trusted person will take an effort to meet the obligation, acting in the interest of the trusting party [Quigley et al. 2007, pp. 71-88].

Two sources of interpersonal trusts are indicated in the literature: cognitive (rational) and affective (relative, based on emotions) and three main dimensions: 
partner's competences, kindness, and reliability and integrity. These factors shape trust both individually and as a whole, and their importance depends on the situation [Tan and Lim 2009, pp. 45-66].

\subsection{Organisational, normative and team commitment}

Organisational commitment is defined as identification of the employer with the organisation and willingness to work for it. In the literature, it is also defined as a psychological force tying with the organisation, which makes changing workplace less attractive [Johnson et al. 2009, pp. 431-447; Peyrat-Guillard and Glińska-Neweś 2010, pp. 47-64] and expresses the attitude of the employee towards the organisation and its goals, a natural consequence of which is an adequate behaviour of the employee [Kmiotek 2015, pp. 1161-1173]. One may state that building employee's commitment is a challenge for human resources management specialists, as it leads to efficiency increase and to the success of the organisation [Rich et al. 2010, pp. 617-635].

Allen and Meyer indicate three components of organisational commitment [Allen and Meyer 1990, pp. 1-18]. Affective commitment shall be understood as employee's emotional attachment to the organisation, reflecting the degree to which an individual feels the need to act within said organisation, which is related to expressing positive emotional attitude towards it. It results from inner beliefs (e.g. passion, satisfaction), is permanent and authentic. People with a high level of affective commitment identify with the organisation, engage in it, and they are satisfied with realising their professional roles within the organisation. Therefore, this type of commitment is believed to be the most valuable for organisations. In the literature, the relation between affective commitment and work results is emphasised [Angle and Perry 1981, pp. 1-14; Becker and Gerhart 1996, pp. 779-801; Meyer et al. 1989, p. 152, Rakowska and Mącik 2016 pp. 48-58]. Moreover, research shows a negative relation between affective commitment, turnover intention and turnover itself [Meyer et al. 2002, pp. 20-52; Vandenberghe et al. 2009, pp. 331-348].

Continuance commitment refers to possible costs of leaving an organisation. These costs may be increased by perceived lack of alternatives on the labour market [Meyer and Allen 1984, p. 372]. Commitment is often a result of exchange transactions between the employee and the organisation and refers to losing possible advantages in case of employee's resignation (e.g. bonus depending on years in employment, retirement security, sense of security, jubilee bonuses). This type of commitment may mean that the employee stays in the organisation to fulfil his/her own needs. Such an attitude may be also related to the employee's situation, e.g. family problems, health issues, or a vision of the role of work in human life such as its lesser importance of professional life with regard to private life. This attitude is probably related to lack of identification with the company and performing tasks on a basic level. 
Normative commitment is determined by social norms defining the level of loyalty, feeling of obligation, and allegiance towards the organisation. It shows how much one believes that he/she should stay in the organisation. It is also related with responsibility that makes the employee stay [David and Foray 2002, pp. 9-23]. Normative commitment is employee's moral obligation to be with the organisation [Allen and Meyer 1996, pp. 252-276]. Basing solely on this assumption, a given person acts in a given way believing that these actions are appropriate and morally justified. According to social exchange theory, when employees feel that their organisation is giving something of value, they consider it their obligation to respond to the organisation positively [Blau 1964]. Research shows that if an organisation invests in the development of a given employee, he/she may later feel obliged to stay in it [Meyer and Smith 2000, p. 319]. In this context, atmosphere of trust and trust-based relations can be seen as valuable for employees, who may respond with normative commitment. It is worth mentioning that such relation concerns the exchange of values of the same kind, i.e. non-material.

Normative commitment is based on experiences related to socialisation in the family, the society, and the organisation. An employee may feel high normative commitment if important figures in his/her life, e.g. parents, are long-term employees of one company and/or emphasise the importance of loyalty towards organisations. Moreover, a high level of such commitment based on organisational socialisation will occur in the organisation in which it is emphasised and the expectations of loyalty are communicated [Meyer and Smith 2000, p. 319].

In recent years, many publications on the importance of teamwork for organisations have been published [Alder et al. 2012, pp. 1-11]. However, few researchers focused on team commitment. Team commitment is defined as psychological trust of team members to the team. It is similar to organisational commitment, but concerns a team, not the whole organisation the team is a part of [Singh and Gupta 2015, pp. 1192-1211]. Team members may share team goals and values, affect the effects of its work, or value being a part of it to a different extent. The authors [van Dick et al. 2008, pp. 388-399] state that team and organisational commitment may coexist, which is the best situation for the organisation. Research indicates that team trust is a source of many benefits for team work [Bishop et al. 2000, pp. 1113-1132]. It is emphasised that team members for whom participation in a team is a pleasurable experience identify with team goals and values and want to stay in the team to achieve its goals [Neininger et al. 2010, pp. 567-579].

It seems that, analogically to organisational commitment, team commitment has three components: affective - satisfaction of being a team member, continuance - feeling the need to stay in the team because of own motives, and normative. Normative team commitment can be defined as related to feeling obliged to work for the team as a result of moral duty. 


\section{Method}

In the study, the hypotheses about the impact of institutional, vertical and horizontal trust on normative and normative team commitment have been formulated. A quantitative approach was adopted based on the nature of the data. A structured questionnaire was used as the primary data collection instrument. The research involved conducting a survey among 501 employees of organisations and companies operating in Poland.

\subsection{Sample}

The data used in the paper come from the $\mathrm{n}=1,065$ sample - a random representation of the population of Poland aged 18+ by using the CATI (Computer-Assisted Telephone Interviewing) method used in quantitative research. Telephone numbers were randomly selected by using the assisted random digit dialing method. In addition, $70 \%$ of the mobile sample is randomly selected.

Research respondents are also randomly selected from each selected layer. The layers (categories) correspond to the location size (9 categories), their regional distribution (16) and account for the age and sex of selected persons. The sampling process has several stages: stage one involves stratification of the population of Poland based on the territorial location criterion and the class of the location size. The final stage of the research sample selection takes place during its telephone delivery. The IT system supervising the research receives both data on randomly selected telephone numbers as well as the estimated number of the layers (for the macro-regions as well as age, sex and location size categories). The computer randomly assigns telephone numbers to pollsters. At the initial phase of the interview, the pollster selects their respondents from the pool of available candidates by using the standard method and the system automatically supervises following the planned stratification.

For the benefit of the paper, respondents were subject to an additional selection: first, data from people who did not enjoy a working person status at the time of the survey was rejected, second, incomplete observation that is, missing data in the variables forming a part of the measurement model, was rejected. The sample structure shown in Table 1 was calculated for the sample of $n=501$.

Table1. Research sample structure

\begin{tabular}{|c|c|c|c|c|c|}
\hline & Number & $\%$ & & Number & $\%$ \\
\hline \multicolumn{3}{|c|}{ Type of employment } & \multicolumn{3}{|l|}{ Sex } \\
\hline Contract for unspecified period & 357 & 66.4 & Women & 299 & 57.2 \\
\hline Contract for specified period & 123 & 23.4 & Men & 202 & 42.8 \\
\hline Other & 21 & 10.2 & \multicolumn{3}{|l|}{ Position held } \\
\hline \multicolumn{3}{|c|}{ Company's status } & CEO. Owner Managing director & 61 & 13.2 \\
\hline Private sector & 223 & 43.3 & Managerial staff & 88 & 17.6 \\
\hline Public sector & 138 & 27.5 & Specialist & 110 & 24.2 \\
\hline
\end{tabular}


Pobrane z czasopisma Annales H - Oeconomia http://oeconomia.annales.umcs.pl

Data: 26/04/2023 01:33:46

ORGANIZATIONAL TRUST AND NORMATIVE COMMITMENT

\begin{tabular}{|c|c|c|c|c|c|}
\hline & Number & $\%$ & & Number & $\%$ \\
\hline Partnership/cooperative & 106 & 21.6 & Regular employee & 153 & 32.2 \\
\hline International company & 34 & 7.6 & Other & 69 & 12.8 \\
\hline & & & \multicolumn{3}{|c|}{ Seniority in the company } \\
\hline \multicolumn{3}{|c|}{ Education (background) } & Up to 3 years & 142 & 28.3 \\
\hline Primary & 9 & 2.4 & $4-8$ & 133 & 26.6 \\
\hline Vocational & 62 & 13.4 & $9-13$ & 64 & 13.0 \\
\hline Secondary & 205 & 40.0 & $14-18$ & 50 & 9.9 \\
\hline Higher & 225 & 44.2 & 19 and more & 103 & 21.0 \\
\hline \multicolumn{3}{|c|}{ Size of the company (employees) } & I don't remember & 7 & 1.3 \\
\hline$\leq 10$ & 124 & 24.9 & \multicolumn{3}{|c|}{ Age brackets } \\
\hline $11-50$ & 138 & 27.5 & $18-24$ & 32 & 7.2 \\
\hline$\underline{50-250}$ & 103 & 21.0 & $25-34$ & 133 & 26.6 \\
\hline $251-500$ & 33 & 6.7 & $35-44$ & 150 & 29.7 \\
\hline$>500$ & 81 & 15.8 & $45-59$ & 151 & 29.9 \\
\hline Hard to say & 22 & 4.1 & $\leq 60$ & 35 & 6.5 \\
\hline
\end{tabular}

Source: Authors' own study.

\subsection{Measures}

The items on the questionnaire were developed by the author based on the studies of the authors listed in Table 2. Each of the studied dimensions was tested using a measurement scale containing statements with a five-point Likert scale.

Table 2. Constructs

\begin{tabular}{|l|l|}
\hline \multicolumn{1}{|c|}{ Construct } & \multicolumn{1}{c|}{ Bibliographical sources } \\
\hline Institutional (impersonal) trust (6 items) & Ellonen et al. [2008] \\
\hline Vertical trust (6 items) & $\begin{array}{l}\text { Shockley-Zalabak et al. [2000], Huff and Kelley [2003], Tzafrir, } \\
\text { Baruch and Dolan [2004] }\end{array}$ \\
\hline Horizontal trust (6 items) & McAllister [1995], Gillespie [2003] \\
\hline Normative commitment (4 items) & Allen and Meyer [1990] \\
\hline Normative team commitment (2 items) & Lewicka and Książek [2015] \\
\hline
\end{tabular}

Source: Authors' own study.

The normative commitment (4 items) was measured with the items such as "I am convinced that one must be always loyal to their organisation" as well as those that strongly emphasised the obligations towards the company and the team, e.g.: "I know that my colleagues count on me and this is why, at the moment important for me and my team, I would not leave my work just like that", "I feel an internal obligation to work well every day not to let my colleagues down", "I would not take sick leave without a very good reason when the company needs me".

The team normative commitment ( 2 items) was tested based on two statements such as: "I feel an inner duty to work well every day, so as not to disappoint my work colleagues", and "I know that colleagues count on me, and, therefore, would not quit my job overnight at an important moment for the company". 
The vertical trust (6 items) was analysed on the basis of the items which referred to the following: vertical competences of the line manager, keeping promises, open communication, obtaining support and help as well as horizontal trust (6 items): sharing of one's knowledge, keeping promises, integrity, etc. Institutional (impersonal) trust (6 items) was measured with statements such as: "In my company, the company's principles and standards are observed", "My company is well managed", "In my company, conflicts are solved on an on-going basis".

Measurement scales used in measurement parts of estimated models are reliable and valid. Cronbach's alpha coefficient for institutional, vertical, horizontal trust and normative commitment exceeds the usually required value of 0.7 . For the construct: normative team commitment alpha is below 0.7 , the dimension consists of only 2 items, so alpha over 0.6 is required [Nunnally et al. 1967].

\section{Results}

\subsection{The normative commitment}

The standard variable regression analysis was performed in order to determine the factors affecting the normative commitment. It was assumed that the normative commitment is influenced by three dimensions of organizational trust: institutional (impersonal), vertical and horizontal. Statistical significance was proved for all three explanatory variables.

Below, an econometric model is presented in which the independent variables are: $\mathrm{x}_{1}$ - horizontal trust, $\mathrm{x}_{2}-$ vertical trust, $\mathrm{x}_{3}$ - institutional trust; the dependent variable is $\mathrm{y}-$ normative commitment. The model is presented as follows:

$$
Y=0.3 X_{1}+0.15 X_{2}+0.135 X_{3}+0.16
$$

Table 3. The effect of trust on the normative commitment

\begin{tabular}{|c|c|c|c|c|c|c|}
\hline \multirow[t]{2}{*}{$\mathrm{N}=501$} & \multicolumn{6}{|c|}{$\begin{array}{l}\text { The summary for the dependent regressive variable: NORMATIVE COM- } \\
\text { MITMENT } \mathrm{R}=.60870888 \mathrm{R}^{\wedge} 2=.37052651 \text { correct. } \mathbf{R}^{2}=. \mathbf{3 7} \\
\mathrm{F}(3,497)=97.516, \mathrm{p}<0.0000, \text { Std. estimation error: } .58768\end{array}$} \\
\hline & $b^{*}$ & Std. error & b & Std. error & $\mathrm{t}(497)$ & $\mathrm{p}$ \\
\hline Free indicator & & & 1.62 & 0.14 & 11.57116 & 0.000000 \\
\hline Institutional Trust & 0.18 & 0.06 & 0.135 & 0.05 & 2.89 & 0.004058 \\
\hline Horizontal Trust & 0.30 & 0.04 & 0.30 & 0.05 & 6.14 & 0.000000 \\
\hline Vertical trust & 0.21 & 0.05 & 0.15 & 0.04 & 3.71 & 0.000233 \\
\hline
\end{tabular}

* - standardized regression coefficients

Source: Authors' own study. 
The study found that all types of trust influence the normative commitment, with the horizontal trust exerting the strongest influence, which proved the hypothesis set. Hence, conclusion must be drawn that with one unit of horizontal trust increase normative commitment will rise by 0.3 units and in the case of vertical and institutional the proportion will be 0.15 and 0.135 units, respectively. The $\mathrm{R}^{2}$ of 0.37 indicates that the model is reflected in $37 \%$ of cases.

\subsection{The normative team commitment}

The next step of the research examines which factors have an impact on the normative team commitment, which is understood as a sense of team duty, pertaining to the team whose member is the research respondent. It was assumed that, as in the previous case, the standard attachment is affected by three dimensions of organizational trust. Statistical significance was proved for all three explanatory variables.

Below, an econometric model is presented in which the independent variables are: $\mathrm{x}_{1}$ - horizontal trust, $\mathrm{x}_{2}-$ vertical trust, $\mathrm{x}_{3}$ - institutional trust; the dependent variable is $\mathrm{y}$-normative team commitment. The model is presented as follows:

$$
Y=0.5 X_{1}+0.12 X_{2}+0.14
$$

Table 4. Relation of trust to the normative team commitment

\begin{tabular}{|c|c|c|c|c|c|c|}
\hline \multirow[t]{2}{*}{$\mathrm{N}=501$} & \multicolumn{6}{|c|}{$\begin{array}{l}\text { The summary for the dependent regressive variable: TEAM NORMATIVE } \\
\text { COMMITMENT } \mathrm{R}=.63511910 \mathrm{R}^{\wedge} 2=.40337627 \text { correct. } \mathbf{R}^{2}=4 \mathrm{~F}(3,497)= \\
112.01, \mathrm{p}<0.0000, \text { Std. estimation error: } .66201\end{array}$} \\
\hline & $\mathrm{b} *$ & Std. error & $\mathrm{b}$ & Std. error & $\mathrm{t}(497)$ & $\mathrm{p}$ \\
\hline Free indicator & & & 1.40 & 0.15 & 8.821964 & 0.000000 \\
\hline Horizontal trust & 0.44 & 0.05 & 0.50 & 0.05 & 9.36 & 0.000000 \\
\hline Vertical trust & 0.14 & 0.05 & 0.12 & 0.05 & 2.6 & 0.009381 \\
\hline Institutional trust & 0.11 & 0.06 & 0.10 & 0.05 & 1.9 & 0.056738 \\
\hline
\end{tabular}

* - standardized regression coefficients

Source: Authors' own study.

Both types of interpersonal trust relate to the normative team commitment. The impact of institutional trust variable, even though entered into the research model, is negligible and statistically insignificant. This means that the horizontal trust increment of one unit corresponds to an increase of 0.5 units for the normative team commitment, whereas the same increase of vertical trust coincides with 0.12 units. The value of $\mathrm{R}^{2}=0.4$ indicates that the model is matched in $40 \%$ of cases. 


\section{Conclusions}

The obtained results allow for the confirmation of accepted hypotheses regarding the impact of trust on the normative commitment and normative team commitment. The created models make it possible to rank the impact of particular types of trust from the most to the least affecting.

The results also imply the horizontal trust bears the greatest significance on normative commitment. It should also be emphasized that the hypothesis about the impact of vertical and institutional trust have been confirmed with obtained dependencies clearly weaker.

The study denotes that the significant impact of horizontal trust on normative team commitment should not be unexpected. Team trust is founded in the expectation that the working employee will take the team interest into account. And conversely, the normative team involvement is the inner obligation to such action. Also, the impact of vertical trust on team normative commitment has been positively verified. There is no evidence, however, that the institutional trust affects normative team commitment.

These results suggest that both types of normative commitment are correlated more with interpersonal than institutional trust. They relate more to colleague relationship than can be linked to employee-organisation relationship. This research outcome might be related to the general trend of loosening organization ties and the increasing popularity of flexible employment forms, and, as a consequence, among others, the change of psychological contract from relational to a more calculated one [Saunders and Thornhill 2006, pp. 449-467]. This might be due to shifting work in organizations towards design and project teams.

The achieved $\mathrm{R}^{2}$ results implies that these models explain certain degree of variability in the data ( $37 \%$ and $40 \%$, respectively). This result is the source of significant managerial implications. It constitutes the support for the thesis of the necessity for deliberately building trust, in this case, especially in relation to interpersonal links and particular teams [Rakowska 2011, pp. 5-18].

So far, few studies have been devoted to importance of horizontal trust in organizations, shifting the focus to vertical trust. Therefore, the essential complement to this research would be to clarify the relationship between the two constructs, addressing the question of how the different types of trust with particular emphasis on horizontal trust have an effect on normative commitment and team normative commitment. It would be advisable to attempt to identify other factors bearing on the standard attachment, among which respondents' personality traits and other organizational factors, e.g. support organization (POS), organizational justice, etc. would be worth taking into account. In the course of further research, attention should be focused on confirming the overall model of the impact variables tested on organizational commitment based on the of structural equation modeling method (SEM). 


\section{Bibliography}

Alder, G.S., McAllister, D., Chase, J., We Get By With a Little Help from Our Friends: Exploring the Effects of Perceived Coworker Support on Employee Burnout and Job Attitudes, "Advances in Business Research" 2012, vol. 3, no. 1, pp. 1-11.

Allen, N.J., Meyer, J.P., The Measurement and Antecedents of Affective, Continuance and Normative Commitment to the Organization, "Journal of Occupational and Organizational Psychology" 1990, vol. 63 , no. 1, pp. 1-18.

Allen, N.J., Meyer, J.P., Affective, Continuance, and Normative Commitment to the Organization: An Examination of Construct Validity, "Journal of Vocational Behavior" 1996, vol. 49, no. 3, pp. 252-276.

Angle, H.L., Perry, J.L., An Empirical Assessment of Organizational Commitment and Organizational Effectiveness, “Administrative Science Quarterly" 1981, vol. 26, no. 1, pp. 1-14.

Becker, B., Gerhart, B., The Impact of Human Resource Management on Organizational Performance: Progress and Prospects, "Academy of Management Journal” 1996, vol. 39, no. 4, pp. 779-801.

Bishop, J.W., Scott, K.D., Burroughs, S.M., Support, Commitment, and Employee Outcomes in a Team Environment, "Journal of Management" 2000, vol. 26, no. 6, pp. 1113-1132.

Blau, P.M., Exchange and Power in Social Life, Transaction Publishers, New Brunswick-London 1964.

Blomqvist, K., Partnering in the Dynamic Environment: The Role of Trust in Asymmetric Technology Partnership Formation, Lappeenranta University of Technology 2002.

Brockner, J., Siegel, P.A., Daly, J.P., Tyler, T., Martin, C., When Trust Matters: The Moderating Effect of Outcome Favorability, "Administrative Science Quarterly" 1997, vol. 42, no. 3, pp. 558-583.

Cascio, W.F., Downsizing: What Do We Know? What Have We Learned?, "The Academy of Management Executive" 1993, vol. 7, no. 1, pp. 95-104.

Cho, Y.J., Park, H., Exploring the Relationships Among Trust, Employee Satisfaction, and Organizational Commitment, "Public Management Review" 2011, vol. 13, no. 4, pp. 551-573.

Conger, J.A., Kanungo, R.N., Menon, S.T., Charismatic Leadership and Follower Effects, "Journal of Organizational Behavior" 2000, vol. 21, no. 7, pp. 747-767.

Connell, J., Ferres, N., Travaglione, T. (2003). Engendering Trust in Manager-Subordinate Relationships: Predictors and Outcomes, "Personnel Review" 2003, vol. 32, no. 5, pp. 569-587.

David, P.A., Foray, D., An Introduction to the Economy of the Knowledge Society, "International Social Science Journal" 2001, vol. 54, no. 171, pp. 9-23.

Dirks, K.T., Ferrin, D.L., Trust in Leadership: Meta-Analytic Findings and Implications for Research and Practice, "Journal of Applied Psychology" 2002, vol. 87, no. 4, pp. 611-628.

Ellonen, R., Blomqvist, K., Puumalainen, K., The Role of Trust in Organisational Innovativeness, "European Journal of Innovation Management" 2008, vol. 11, no. 2, pp. 160-181.

Fukuyama, F., Zaufanie: kapitat społeczny a droga do dobrobytu, Wydaw. Naukowe PWN, Warszawa 1997.

Gaur, A., Mukherjee, D., Gaur, S., Schmid, F., Environmental and Firm Level Influences on Inter-Organizational Trust And SME Performance, "Journal of Management Studies" 2011, vol. 48, no. 8, pp. 1752-1781

Gillespie, N., Measuring Trust in Working Relationships: The Behavioral Trust Inventory, working paper, the Academy of Management Conference, Seattle, WA 2003 (August).

Gilson, L., Trust and the Development of Health Care as a Social Institution, "Social Science \& Medicine" 2003, vol. 56, no. 7, pp. 1453-1468.

Glińska-Neweś, A., Employee Interpersonal Relationships, [in:] M.J. Stankiewicz (ed.), Managing the Key Areas of Positive Organisational Potential for Company Success, Dom Organizatora TNOiK, Toruń 2013, pp. 125-154.

Huff, L., Kelley, L., Levels of Organizational Trust in Individualist Versus Collectivist Societies: A Seven-Nation Study, "Organization Science" 2003, vol. 14, no. 1, pp. 81-90. 
Johnson, R.E., Groff, K.W., Taing, M.U., Nature of the Interactions Among Organizational Commitments: Complementary, Competitive or Synergistic?, "British Journal of Management" 2009, vol. 20, no. 4, pp. 431-447.

Kmiotek, K., Uwarunkowania zaangażowania profesjonalnego pracowników na stanowiskach inżynierskich "Marketing i Rynek" 2015, (5 (CD)), pp. 1161-1173.

Koźmiński, A.K., Zarządzanie w warunkach niepewności: podręcznik dla zaawansowanych, Wydawnictwo Naukowe PWN, Warszawa 2004.

Lewicka, D., Książek, D., Rola zaufania jako czynnika wzmacniającego zaangażowanie afektywne pracowników w polskich organizacjach, "Marketing i Rynek" 2015, (5 (CD)), pp. 1174-1185.

Loon Hoe, S., Shared Vision: A Development Tool for Organizational Learning, "Development and Learning in Organizations: An International Journal" 2007, vol. 21, no. 4, pp. 12-13.

McAllister, D.J., Affect-and Cognition-Based Trust as Foundations for Interpersonal Cooperation in Organizations, "Academy of Management Journal" 1995, vol. 38, no. 1, pp. 24-59.

Meyer, J.P., Allen, N.J., Testing the "Side-Bet Theory" of Organizational Commitment: Some Methodological Considerations, "Journal of Applied Psychology" 1984, vol. 69, no. 3, pp. 372-378.

Meyer, J.P., Allen, N.J., A Three-Component Conceptualization of Organizational Commitment, "Human Resource Management Review"1991, vol. 1, no. 1, pp. 61-89.

Meyer, J.P., Smith, C.A., HRM Practices and Organizational Commitment: Test of a Mediation Model, "Canadian Journal of Administrative Sciences" 2000, vol. 17, no. 4, pp. 319-331.

Meyer, J.P., Paunonen, S.V., Gellatly, I.R., Goffin, R.D., Jackson, D.N., Organizational Commitment and Job Performance: It's the Nature of the Commitment That Counts, "Journal of Applied Psychology" 1989, vol. 74, no. 1, pp. 152-156.

Meyer, J.P., Stanley, D.J., Herscovitch, L., Topolnytsky, L., Affective, Continuance, and Normative Commitment to the Organization: A Meta-Analysis of Antecedents, Correlates, and Consequences, "Journal of Vocational Behavior" 2002, vol. 61, no. 1, pp. 20-52.

Morgan, R.M., Hunt, S.D., The Commitment-Trust Theory of Relationship Marketing, "The Journal of Marketing" 1994, vol. 58, no. 3, pp. 20-38.

Neininger, A., Lehmann-Willenbrock, N., Kauffeld, S., Henschel, A., Effects of Team and Organizational Commitment - a Longitudinal Study, "Journal of Vocational Behavior" 2010, vol. 76, no. 3, pp. 567-579.

Nunnally, J.C., Psychometric Theory, McGraw-Hill, New York 1967.

Peyrat-Guillard, D., Glińska-Neweś, A., Positive Organizational Potential, Organizational Commitment And Organizational Citizenship Behavior: A French/Polish Comparison, "Journal of Positive Management" 2010, vol. 1, no. 1, pp. 47-64.

Pirson, M., Malhotra, D., Unconventional Insights for Managing Stakeholder Trust, "MIT Sloan Management Review" 2008, no. 49, 43-50.

Quigley, N.R., Tesluk, P.E., Locke, E.A., Bartol, K.M., A Multilevel Investigation of the Motivational Mechanisms Underlying Knowledge Sharing and Performance, "Organization Science" 2007, vol. 18, no. 1, pp. 71-88.

Rakowska, A., Mącik, R., Zaangażowanie pracownika a satysfakcja z pracy-modelowanie zależności z wykorzystaniem PLS-SEM, "Przegląd Organizacji” 2016, no. 5, pp. 48-58.

Rakowska, A., Kryzysowe przywództwo, czyli kompetencje menedżerskie niezbędne w trudnych czasach, "Organizacja i Zarządzanie" 2011, vol. 2, no. 14, pp. 5-18.

Reina, D.S., Reina, M.L., Trust and Betrayal in the Workplace: Building Effective Relationships in Your Organization, Berrett-Koehler Publishers, Oakland, CA 2006.

Rich, B.L., Lepine, J.A., Crawford, E.R., Job Engagement: Antecedents and Effects on Job Performance, "Academy of Management Journal" 2010, vol. 53, no. 3, pp. 617-635.

Saunders, M.N., Thornhill, A., Forced Employment Contract Change and the Psychological Contract, "Employee Relations" 2006, vol. 28, no. 5, pp. 449-467. 
Shockley-Zalabak, P., Ellis, K., Winograd, G., Organizational Trust: What It Means, Why It Matters, “Organization Development Journal" 2000, vol. 18, no. 4, p. 35.

Singh, A., Gupta, B., Job Involvement, Organizational Commitment, Professional Commitment, and Team Commitment: A Study of Generational Diversity, "Benchmarking: An International Journal” 2015, vol. 22, no. 6, pp. 1192-1211.

Sitkin, S.B., Roth, N.L., Explaining the Limited Effectiveness of Legalistic "Remedies" for Trust/Distrust, "Organization Science" 1993, vol. 4, no. 3, pp. 367-392.

Svensson, G., Multiple Informants and Asymmetric Interactions of Mutual Trust in Dyadic Business Relationships, "European Business Review” 2006, vol. 18, no. 2, pp. 132-152.

Tan, H.H., Lim, A.K. Trust in Coworkers and Trust in Organizations, "The Journal of Psychology" 2009, vol. 143, no. 1, pp. 45-66.

Turner, H.H., Struktura teorii socjologicznej, Wyd. Naukowe PWN, Warszawa 2004.

Tzafrir, S.S., Baruch, Y., Dolan, S.L., The Consequences of Emerging HRM Practices for Employees'Trust in Their Managers, "Personnel Review" 2004, vol. 33, no. 6, pp. 628-647.

Valaei, N., Rezaei, S., Job Satisfaction and Organizational Commitment: An Empirical Investigation Among ICT-SMEs, "Management Research Review” 2016, vol. 39, no. 12, pp. 1663-1694.

Van Dick, R., van Knippenberg, D., Kerschreiter, R., Hertel, G., Wieseke, J., Interactive Effects of Work Group and Organizational Identification on Job Satisfaction and Extra-Role Behavior, "Journal of Vocational Behavior" 2008, vol. 72, no. 3, pp. 388-399.

Vandenberghe, C., Bentein, K., A Closer Look at the Relationship Between Affective Commitment to Supervisors and Organizations and Turnover, "Journal of Occupational and Organizational Psychology" 2009, vol. 82, no. 2, pp. 331-348.

Vanhala, M., Heilmann, P., Salminen, H., Organizational Trust Dimensions as Antecedents of Organizational Commitment, "Knowledge and Process Management" 2016, vol. 23, no. 1, pp. 46-61.

Vidotto, G., Vicentini, M., Argentero, P., Bromiley, P., Assessment of Organizational Trust: Italian Adaptation and Factorial Validity of the Organizational Trust Inventory, "Social Indicators Research" 2008, vol. 88, no. 3, pp. 563-575.

Zhang, A. Y., Tsui, A. S., Song, L. J., Li, C., Jia, L., How Do I Trust Thee? The Employee-Organization Relationship, Supervisory Support, and Middle Manager Trust in the Organization, "Human Resource Management" 2008, vol. 47, no. 1, pp. 111-132.

\section{Organizational Trust and Normative Commitment}

The purpose of this study is to investigate the impact of the institutional, vertical and horizontal trust upon normative and normative team commitment. The survey of 501 randomly selected employees was conducted in Poland. The method of multiple regression analysis was used in order to test hypotheses on the impact of different types of organizational trust on the normative and normative team commitment. The results indicate that the horizontal trust exerts the greatest influence on both types of normative commitment. Impact of institutional trust on normative team commitment has not been confirmed.

\section{Zaufanie organizacyjne a przywiązanie normatywne}

Celem artykułu jest zbadanie wpływu zaufania instytucjonalnego, wertykalnego oraz horyzontalnego na przywiązanie normatywne i normatywne zespołowe. Badanie zostało przeprowadzone w Polsce wśród 501 losowo wybranych pracowników. Metoda analizy regresji wielokrotnej została wykorzystana w celu weryfikacji hipotez o wpływie poszczególnych rodzajów zaufania organizacyjnego na przywiązanie normatywne i normatywne zespołowe. Uzyskane wyniki wskazują, że zaufanie horyzontalne wywiera największy wpływ na oba rodzaje przywiązania normatywnego. Nie potwierdzono wpływu zaufania instytucjonalnego na przywiązanie normatywne zespołowe. 